\title{
Role of Professional Bodies to Improve the Education and Professionalism
}

\author{
Iqbal Shaukat \\ Canadian Association of Post Doctoral Scholar, Toronto, Canada
}

Email address:

professionalstudent2020@gmail.com

To cite this article:

Iqbal Shaukat. Role of Professional Bodies to Improve the Education and Professionalism. Science Journal of Education. Vol. 9, No. 5, 2021, pp. 143-148. doi: 10.11648/j.sjedu.20210905.11

Received: August 1, 2021; Accepted: September 2, 2021; Published: September 10, 2021

\begin{abstract}
Professional bodies are an integral part of the country's economy, without the professional bodies their dream of development cannot be fulfilled. Professional bodies play an integral role in professional education and training and professional opportunities. In various countries of the world, professional bodies have a big share in the country's development. Professional bodies provide skilled manpower for professional work. Professional bodies work for the welfare of society. Professional bodies delegation go to overseas in various countries and exchange the views regarding the services. Professional bodies arrange the finance for the poor students regarding education. Professional bodies publish the journal for the student in which all the matters are discussed. Professional bodies give the opportunity to scholar to write down various issues. Professional bodies have arranged the promotion of Professional institutes. Professional institutes arrange various conferences for the member regarding the economic situation. Professional bodies increase the education standers. Professional bodies are working for the promotion of education. Professional bodies have arranged the corporation with the resemble institute. professional bodies are playing a very dynamic role in the era of globalization professional bodies are playing a dynamic role in developing and as well as developed countries.
\end{abstract}

Keywords: Professional, Bodies, Skill

\section{Introduction}

Professional education provide the training to student regarding the how to work. Professional institutes give the guide line to institutes how to training for the student. Professional institutes set the stander of training stander for the student. Professional institute arrange the clients for the Professional bodies. Professional bodies work for the welfare of society. Professional bodies delegation go to overseas in various countries and exchange the views regarding the services. Professional bodies arrange the finance for poor student regarding the education. Professional bodies publish the journal for the student in which all the matters are discussed. Professional bodies give the opportunity to scholar to write down the on various issues. Professional bodies are arranging the promotion of Professional institutes. Professional institute arrange the various conferences for the member regarding economic situation. Professional bodies increase the education standers. Professional bodies are working for promotion of education. Professional bodies are arrange the corporation with the resemble institute. Professional bodies are watching the bodies of other bodies how they are working for the development of education. Professional institute give the guideline to the student how they get the job. Professional bodies arrange the examination for the assessment of relent of student. The arrange of examination for student are very important they maintain the stander of examinations. Professional bodies formulate the syallbus for examination. Professional bodies are arranging the best faculty who are expert in evalution and assessment. Professional bodies arrange the tutor ship for student who give the best education and tutor services to students. Professional bodies arrange the better infrastructure for the premises. Professional bodies are working for the recognition of professional certificate. Professional bodies give the subsidy to the poor student. The allocation of funds is very important function of professional bodies [1-6]. 


\section{Professional Bodies Role in Present Secnarios}

Professional bodies arrange the faculty from developed countries like USA, Canada and UK, this faculty help the running faculty in which the stander of education more increase. Professional bodies are arranging the contact with author and writer to read the books on particular topics. Professional bodies make the strategy how to increase the quality of education regarding the tutor and education. Professional bodies are creating the environment for the student in which they get the more good education. The basic purpose of professional education is to provide the education in the country. The fundamental purpose of professional is to provide the talent who provide the opportunity to country in the field of development. Professional bodies play the role of value addition in economy. When we considering the role of professionals. The role of professional is very important. Professional give the good output. For example the professional engineer plays the dynamic role in the promotion and engineering the resource. Professional engineer know how to utilize the resources of one project. Engineer know how the project is completed in stipulated time, he know how the team work is being organized in the one project. In various fields like purchase of material is very important. Professional person in this regard play the dynamic role regarding the purchase of material. Professional person use the different model of material and select the model of material which is very useful for the organization. Professional person played the dynamic role regarding the material management. Professional person played the dynamic role availability of material at the proper time. Quality assurance is the important part of country economy. With the help of Professional person we measure the quality control very well. With the help of professional person we can reach the suitable stander of the any commodity. In field of Accountancy the role of professional person is very important. The professional Accountant prepares the Account report. He knows the stander of accounts.

He estimates the financial positions of companies.

Professional Auditor are very important the country economy. Professional Auditor plays the dynamic role transparency of accounts. Professional auditor how to make compline with laws and regulations. Managerial Accounts is very important for the management side. With the help of managerial Accounting we can easily give reports of different segments. Accountancy help maintain the record With the help of accounting we can maintain our accounts when it is expended on the massive line Just like Branch accounts We can consolidate our business report in the easily ways, with the help of accounting practice We can establish our financial leverage such as ratio to estimate the solvency position and debt equity ratio and regarding other financial issues With the help of accountancy we can prepare all the report for all management levels Amalgamation and reconstruction process of various companies supported by accounting principles and stander With the help accountancy we prepare the budget according to the need of business with the help of art of accountancy we maintain the record of financial record of all financial instruments like shares, debentures Accountancy art help to calculation of costing of good sold With the help of accountancy we can calculate the various type of cost which are very vital for the manufacturing sector like factory overheads and other cost which are essential for business world With the help of accounting we can prepare the reward report for labors like bonus plan and wages rates Accountancy help you to prepare the report of various department of various textile sectors Accountancy helps the man in other sector like leasing for the completion of term and conditions [2-16].

\section{Example the Role Professional Bodies Regarding Professional Fields}

Accountancy is very beneficial for the client regarding establish of good relation and maintain of accuracy of all transactions Accountancy help you to estimate the risk in business between the events Calculation of risk provide the stander of accuracy between the events Accountancy helpful for the services sector of one country With the help of accountancy we can measure the monetary value of services In the light of arguments it can be said accounting and accountant is very beneficial for the country economy Accountancy helps the gathered the data about Country performance in economic sectors We can measure the total income of the country and estimate all the monetary value of all the services sector like telecommunication and energy sectors Accountancy helps the country to value the balance of trade in monetary value with the rest of world Balance of payment is very crucial for every country Accounting system help you to estimate the monetary value of balance of payment with rest of world Accountancy helps the country on the macro level and micro level Thus, we can say every government should encourage the profession of accountancy Government should establish such vocational institutes which provide the training to the accounts Because of the role of accountant transparency can be brought in the financial matters Accounting system provide the opportunity transparency and true and fairness and accuracy according to governing laws Type of Accounting personal accounts in which we debit the receiver and credit the giver in which we consider the personal account Real account we consider the Debit the assets and credit the liabilities Real account we included the Assets and liabilities Nominal account in which we consider the Debit the expenses and credit the income Thus, we can the import accounts heads Debts; creditor; Assets; Liabilities; expenditure income.

These are the main heads of accounts Because of the classification we can record the transaction and prepare the financial analyses and final accounts and profit and loss account and balance sheet accounting system success full with the role of Accountant Accountants record the transaction and record in the ledger and make the trial 
balance and the finalization of accounts and made the make reconciliation statement and make the subsidiary ledger of various accounts and make the voucher of various transaction of accounts and record the transaction in ledger Reconciliation of various head of accounts make the accuracy of a account Deposited the tax in treasure and other payment which is relevant in labor department regarding the welfare of employees Accountant makes the financial statement Maintain the cash book Provide information regarding the accounts to financial officer Maintain the file of various head of accounts Deposit the utilities bills to various department Maintain the record of payment of utilities bills Maintain the record of salary advances The role of finance manager in accounting system Finance manager analyzes the market finance manager make cash manager finance manager make the cash flow statement Finance management draw the cash manager Finance manager arrange the fund for finance.

Finance manager negotiation with financial institution regarding loan Finance manager negotiations with lease institution Finance manager draw the budget Finance manager make decision of investment according to the operation of business finance manager makes trend analyze Finance manager have the proper survey regarding the stock market Finance manager performs the role of company secretary Finance manager call the Annual general meeting and extra ordinary general meeting Finance manager publish the notice of annual general meeting Finance manager file the annual return in security and exchange commission Finance manager submit all relevant form which is required by corporate laws Finance manager arrange the mediation when some conflicts arise Finance manager arrange the ratio analyze for the view of financial positions Finance manager play role regarding the impairment of assets Finance manager analyze the risk between the event Finance manager forecast of financial position Finance manager give decision regarding the operation management Finance manager arrange the investment opportunities for the company Finance manager conduct the audit according to the legal requirement Finance manager arrange the better flow of funds Finance manager prepare the financial report according to the international slanders Finance manager prepare the cash management Finance manager draw the master budget according to the company needs Finance manager look after all the procedure of allotment of shares The auditor can perform the role with the possible of good accounting system when we have the good accounting system the auditor audit the accounts properly according to the companies it is essential that the accounts should be prepared according to the corporate laws the present of good accounting there will be qualification on accounts with the good accounting system auditor establish the opinion the investment was incurred according to the purpose which is stated in the corporate laws Auditor may find can transaction is held is transparent and good in the presence of good audit system audit can easily check the expenditure according to the purpose With the help of good accounting that director and other high management not run according to the own interest Auditor checks the flow of investment with the help of good accounting system Auditor easily check that amount posted in relevant accounts properly With the help of good accounting system auditor check the banking transaction and match with bank During the good accounting system auditor verify all the agreement with vendors, auditor check that the business is being run by the management of company according to the proper term and conditions Auditor can check the tax deduction of on various payment Auditor checks the originality of transactions with the help of good accounting system With the help of good accounting system that the payment is verified according to roles with the help of good accounting system stream line all transaction of business Auditor checks the employee welfare system with the help of good accounting system that all the payment is being deposited according to the rules and regulations Auditor can point out all the mistake according to the audit frame work With the help of good accounting system that the directors or any other high officer of company influence the business decision presence good accounting system auditor audit verify the stock according to the rules and regulations Auditor can give the advice regarding the business operations in the presence of good accounting system Auditor checks the expenditure incurred according to corporate laws of the relevant country present of good accounting system auditor devalue of assets according to the rules and regulation of assets regulation which is expressed in the corporate laws During the good accounting system auditor check and verify that companies management comply all the regulation of the corporate and companies laws Auditor checks the statutory books of company In presence of good accounting system auditor check that finance manager use the investment according to the purpose In present of good accounting system the Auditor estimate all the resource including finance and corporate Finance manager response on the notice of tax department and security and exchange commission of country Taxation is the important part of country economy Accounting system help the both tax payer and government side to built system with the help of good accounting system we can calculate the taxable income easily and accurate Good accounting system help to calculate the head of total income with the help of good accounting system we can calculate the exemption in tax income With the help of accounting system we calculate all average relief which accurately mentioned in taxation laws we evaluate the value of assets according to laws Good accounting system help the corporate regarding the file of return Association of person can easily file the return with the help of good accounting system Good accounting system is very beneficial when the tax is deducted be the authority With the help of good accounting system the tax on goods and services easily calculated In case when we file the appeal against the tax authority good accounting system help in this regard Statement which is filed by the taxpayer time to time good accounting system help in this regard Good accounting system create the good relation between the customer Good accounting system help the customer when they needed some 
information regarding tax and finance Good accounting provide the opportunity to customer regarding the reconciliation of financial matters Some time customer preserve the financial information for own purpose good accounting system help in this regard some time during asessment year tax payer want.

Sue the claim of over tax liability Good accounting system help the calculation in wealth tax Good economic system help the valuation of assets Wealth tax liability can be easily calculated with the help of good accounting system Various statement can be acquired be by the tax authority can be properly filed with the help of good accounting system wealth statement is mandatory for all the taxpayer proper data can be filed in the presence good accounting system Good Accounting is beneficial for the sales tax correct input and output can be calculated with the help of good accounting system Drawback of duties can be only possible if we have good accounting system Good accounting system help in the calculation of final sales liability Custom duties are the integral part of taxes In the light of good accounting system calculation of duties is very easy There is no chance of evasion of duties when the good accounting system is exit Good accounting system help the importer and exporter valuation of good under the relevant custom law of country In the presence of good accounting system we can fight the legal case of duties easily Good accounting system maintain all the record the custom duties and tariff In the case of drawback of duties the claim is more reliable in the present of good accounting system Excise duties are also the important part of taxation system Reliable accounting record help in how the excise duty is leveled a various items Good accounting system show the payment of payment of excise duty properly Thus, we can good accounting system help the government and taxpayer In the economic survey side accounting system how to get the proper price properly with the help of accounting we can get the proper sample size of various classes of goods Accountancy helps the importer and exporter to maintain the account in the name of exporter and importer both exporter and importer maintain the account which the good are delivered and accepted Both exporter and importer record the expenses Accounting system very beneficial for both parties that reconcile account easily Because of accounting system both calculated the abnormal and normal losses Good accounting system help the reconciliation between the head office and factory The benefit of that there is no chance of fraud between the head office and factory Good accounting system provide the opportunity of consolidation of accounts in that case if your company are the parent and subsidiary or parent of other company, we can easily merge our account and get the maximum profitability of business Good accounting system help the business entity to implement on the accounting and reporting stander The benefit of that maintain of accounting according to corporate laws which is exit in country In that case if two business entities on common objectives They can easily maintain the joint venture account In joint venture account both parties record the transaction of business according to business nature InGood accounting system rectify the wrong entry according to the rules and regulations when the good accounting system exit we can calculate cost volume analysis Good accounting system helps built the effective cash flow statement Cash flow statement consists on operating investing and financing activities cash flow system helps to calculate the profitability of business and budgeting of business Good accounting system evalutes of cost of good sold with invoice price We can calculate the absorption cost Good accounting system helps to calculate the present value method Present value method calculate what is the present value of investment which are invested, with help of cash flow statement Good accounting system helps the future value of investment Future value investment determine the future value of investment With the help of good accounting system we can calculate internal rate of return Internal rate of return express the highest rate of return Good accounting system helps regard the portfolio investment portfolio investment is very important for investor In this investment the investors decide what proportion of investment is done in activities Good accounting system guide how to deal with international financial institutes in exchange rate Exchange rate is very important in international trade international trade is very attach with exchange rate in international trade all issues are settled including hedging and ups and down trend With the good accounting system we can get the better interest model which is important for finance management With the help of good accounting system.

Good accounting system analyze the financial statement with the help of good accounting system we can analyze the financial statement at every time example of financial analyze final account, Bank reconciliation statements Income statement horizontal analysis trend and Vertical analyze trend analyze is very important for business, this analyze to help to estimate the financial position quarterly and annually Analysis is very important for the company directors and shareholder Good accounting system is very important for the corporate finance corporate finance mean that companies subscribed the capital from the shareholders and loan from the banking and financial institution With the help of accounting system company manage the corporate finance easily and watch the back end resource how to safe this finance from risk factor and right accounting treat meant of all corporate finance transaction Accounting system help how to manage the better return of corporate finance Accounting system provide the breakup of corporate finance Good accounting system help the better utilization of corporate finance according to the need With the better accounting we can better utilization of resources Better accounting system help how to reinvest in the various resource and calculate the expected rate of return Good accounting system help the monitoring the all activities regarding the corporate finance Auditor are very aware with the activity of corporate finance with the help of good accounting system With the help of good accounting system we can calculate employee compensation easily calculated 
Intangible assets are the important part of business operation With the help of role of accountancy we can maintain the accounts of intangible assets for example goodwill promoter expenses copy and patent right these are the very important for business At the end of year we create the reserve just like depreciation of tangible assets with the help of sound accountancy system we maintain the record of intangible assets cash con version policy is very important regarding business cycle some time we sold and purchase good on credit line with the help of better accounting system we can watch the conversion policy easily cash conversion effect the working capital because it is direct to inventory Cash conversion process is very important for every company cash conversion policy help the maintain of liquidity position with the help of cash conversion policy we can predict the better financial position of company if the company have not good conversion policy company can face the serious melt down Thus we can say that better accounting system is only help to maintain the better conversion policy Consolidated financial statement is the important part of business organization if company have the voting power in other company they can merge the subsidiary accounts in own company accounts The benefit of that we can easily calculate the profitability easily For example any company is the associate of parent company with the help of consolidation of accounts we can express the accounts of other company in one statement Derivative are the very important part of business operation Derivatives calculate the ups and down trend in the price it is only possible when we have accounts of certain transaction which is related to risk and other exchange rates if we have the table of business trend expected rate in the accounting form then we easily calculate and apply very easily derivatives Derivatives are very important for macro and micro economics Derivatives can only possible when we have data about the risk and expected rate of return and future value of funds flow only proper accounting system can help in this process of derivatives Contingent liabilities and assets is the important part of company business without company sound accounting system we can easily maintain the record of continent assets and liabilities Contingent mean which is conditional some event these are very important for business operation For example one company agree on this conditions the company not pay the credit according to the term and conditions they will pay the damages In Accounting system all this transaction should be recorded according to international stander of reporting if company have the contingent liabilities and assets company record company can sue the other easily because it is certified by the auditor if you have not the good accounting system they will face the audit objection according to international reporting stander Fair market value is the important part of business operations Fair market price means difference between the price of good agree by purchaser and customer wailing The difference between the two price is called fair market value The record of market value policy when we have the record the both value we can easily calculate the fair market price.
Conclusions That is true the role of accountancy in the country economy is very important discussed according to my study and observation and research and professional study in the field of accountancy is the back bone of our economy business corporate sector if one accountant and finance manager perform according to the rules and regulation the country run effectively and better according to international financial reporting standers [1-16].

\section{Conclusion}

Professional education is the important part of our nation life.

Country can be developed with the help of professional education professional education is very important for every nation and economy. Professional bodies working for promotion of education and training.

Professional bodies provide the road map to entire nation. Professional bodies are very important for entire nation.

\section{References}

[1] Gerald J. (1980). "Moral responsibility in professional ethics". N. Y. U. L. Rev. 55. Retrieved March 26, 2016.

[2] "IEEE.org Index Page". IEEE.ORG. IEEE.ORG. Archived from the original on 2015-05-15. Retrieved March 26, 2016.

[3] Harvey, L.; Mason, S.; Ward, R. (1995). Role of Professional Bodies in Higher Education Quality Monitoring. Birmingham: Quality in Higher Education Project. ISBN 1-85920-108-3.

[4] Sullivan, William M. (2nd ed. 2005). Work and Integrity: The Crisis and Promise of Professionalism in America. Jossey Bass.

[5] Gardner, Howard and Shulman, Lee S., The Professions in America Today: Crucial but Fragile. Daedalus, Summer 2005. (pgs. 13-14).

[6] Gilbert, D. (1998). The American class structure: In an age of growing inequality. Belmont, CA: Wadsworth Press.

[7] Beeghley, L. (2004). The structure of social stratification in the United States. Boston: Allyn \& Bacon.

[8] Eichar, D. (1989). Occupation and Class Consciousness in America. Westport, CT: Greenwood Press. ISBN 978-0-31326111-4.

[9] Ehrenreich, B. (1989). Fear of falling: The inner life of the middle class. New York: Harper Perennial.

[10] Schmidt, J. (2000). Disciplined Minds - A Critical Look at Salaried Professionals and the Soul-Battering System that Shapes their Lives. Rowman \& Littlefield, pp. 293.

[11] Barker, Richard (July 1, 2010). "The Big Idea: No, Management Is Not a Profession". Harvard Business Review (July-August 2010). Retrieved October 16, 2019 - via hbr.org.

[12] Romme, G. (2016). The Quest for Professionalism: The Case of Management and Entrepreneurship. Oxford: Oxford University Press. Oxford University Press. 28 January 2016. ISBN 978-0-19-873773-5. Retrieved October 16, 2019. 
[13] "Simple Definition of profess". merriam-webster.com. Merriam Webster. 2015. Retrieved 26 March 2016.

[14] "Google Books NGram Viewer". books.google.com/ngrams. 2018. Retrieved 14 November 2018.
[15] "Google Books NGram Viewer (American English)". books.google.com/ngrams. 2018. Retrieved 14 November 2018.

[16] "Google Books NGram Viewer (British English)". books.google.com/ngrams. 2018. Retrieved 14 November 2018. 